\title{
Industrial Organic Chemistry
}

\section{New Dyestuffs Laboratories of I.C.I., Ltd.}

$\mathrm{T}$ HE unprecedented character of the Dyestuffs (Import Regulation) Act of 1920 was both an expression by Parliament of its conviction that an active and flourishing dyestuffs industry is essential to the life of Great Britain, and a recognition of the technical difficulties of developing such an industry in face of the priceless experience and established position of foreign manufacturers. An exhaustive review at the end of the period of ten years, for which the measure was originally enacted, resulted in 1934 in its being made permanent.

The largest of the interests thus sheltered is now known as the Dyestuffs Group of Messrs. Imperial Chemical Industries, Ltd., and the opening on January 11 of its new research laboratories at Blackley afforded a further opportunity of considering the results of the legislative venture of 1920 . The event was thus one of most unusual interest and importance, and attracted a large gathering representative of academic, administrative and manufacturing interests. The impressions gathered can scarcely have been other than of deep satis. faction.

Apart from all that has been done by the Dyestuffs Group in developing the manufacture of products already known, the early discoveries of the ionamine and duranol series of dyestuffs for acetate silk have latterly been supplemented by the solacet and phthalocyanine series. Further, much progress has been made in the direction of that broadening of activity into other closely allied branches of applied organic chemistry which marked the growth of the Continental industry. This must be regarded as a normal and essential feature of healthy development, and one which will confer on the industry as a whole increased stability. Indeed, it is this expansion to include, for example, modern detergents and textile assistants generally, plastics and rubber, medicinal chemicals, insecticides and fungicides, which has led to the provision of the new laboratories. The close interrelationships of these various fields of work were illustrated in the laboratories by an extremely well-organized series of exhibits representative of "Chapters in the Development of Industrial Organic Chemistry", and described in a wellillustrated presentation volume bearing that title, as well as by demonstrations to conducted parties of visitors.

Prior to this, in a happily informal speech which prefaced his performance of the opening ceremony, Mr. John Rogers had indicated the general outlook of the Dyestuffs Group and discussed the conditions which make for success in the type of research for which the new laboratories are designed. His faith in the productivity of abstract research work and the following up of unexpected results, his plea for a long-term policy and his appreciation of the co-operation both with users of his Company's products and with academic institutions, must all meet with the most cordial approval. It cannot be doubted that adherence to this attitude will provide a sure foundation for the future success and prosperity of the Dyestuffs Group and at the same time a most potent stimulus to the development of organic chemistry in Great Britain.

The laboratories have been designed by Mr. Serge Chermayeff and are intended to be only the first instalment of a larger programme. They take up the main block of a three-storey building, $400 \mathrm{ft}$. long, running north and south, and are entered from a corridor on each floor extending along the whole of the west side. Twenty-one separate laboratories of uniform type are thus provided, each with a partial subdivision, by shelving, into units which accommodate one chemist and offer him a measure of privacy. Fume cupboards glazed on both sides and provided with electrical, gas, steam, compressed air, vacuum, and water services back on to the corridors, where removable panels allow easy access to the service pipes. Continuous windows along the east and west sides of the building give a maximum of continual daylight in the laboratories with protection from too great heat of the sun. Ventilation is entirely by conditioned air, separate ducts, of course, being provided to carry away gases from the fume cupboards. The flooring of cork tile eliminates noise from the laboratories, whilst an air of cheerfulness is contributed by the use of different colours against a background of white.

It will thus be seen that to a thoroughly wellinformed and progressive outlook there have now been added amenities which are first-rate from both the rsthetic and the immediately practical points of view. We tender to Messrs. Imperial Chemical Industries, Ltd., our sincere congratulations on these most favourable auspices and at the same time our best wishes for the future success of their enterprise.

J. K.

\section{Wool Industries Research Association}

$\mathrm{T}$ 'HE Wool Industries Research Association's previous report, reviewed in NATURE of January 16,1937 , was an innovation issued for the information of the general public and firms outside the Association, in view of efforts then being made to secure a statutory levy. It is now reported that insufficient additional support has been fortheoming to warrant the introduction of an enabling Bill into Parliament, and this scheme has been dropped for the time being. It is, however, emphasized that nothing has been left undone to urge the claims of research, and the need for its financial support on a scale more adequate to the magnitude of the industry's interests. Meanwhile, generous response has been made by a number of individual firms for the purpose of meeting a serious and unexpected deficit in revenue, and the 